\title{
Endülüs Fâtihlerinden Mûsâ b. Nusayr'in Akibeti
}

\section{İsmail Hakkı ATÇEKEN*}

\section{The Fate of Musa B. Nusayr: \\ One of the Conquerors of al-Andalus}

Citation/(): Atçeken, İsmail Hakkı, (2015). The Fate of Musa B. Nusayr: One of the Conquerors of al-Andalus, Milel ve Nihal, 12 (1), 9-34.

Abstract: Musa b. Nusayr (19-97/640-716) is one of the important conqueror commanders and governors who lived in the first century of Islam. He was appointed as a governor of Ifriqiyya and al-Magrib at the time of the Umayyads. During his governorship, he conquered many areas and some important islands in the Mediterranean. So, the borders of the Umayyads reached at the Atlantic Ocean. Within three years, he conquered Spain (alAndalus) which was geopolitically very important country at the waypoint of Europe for the Muslims with Tarıq b. Ziyad, the governor of Tanja. Musa b. Nusayr's relations with the Caliph Walid b. Abdalmalik and Sulayman b. Abdalmalik and his fate were quite interesting. In this article, Musa b. Nu-sayr's life and conquests have been briefly dealt with and then his relations with both caliphs, his fate and some applications deemed worthy of this conqueror commander have been examined.

Key Words: Musa b. Nusayr, al-Andalus, Conquest of al-Andalus, Fate of Musa b. Nusayr.

* Prof. Dr., Necmettin Erbakan Üniversitesi, İlahiyat Fakültesi, İslam Tarihi Anabilim Dalı [ihatceken@hotmail.com] 
Atıf/C: Atçeken, İsmail Hakkı, (2015). Endülüs Fâtihlerinden Mûsâ b. Nusayr'ın Akibeti, Milel ve Nihal, 12 (1), 9-34.

Öz: Mûsâ b. Nusayr (19-97/640-716) da İslâm tarihinin ilk asłında yaşamış önemli fatih komutan ve valilerden birisidir. 0, Emevîler döneminde vali olarak tayin edildiği Ifrîkıyye ve Mağrib bölgelerinde gerçekleştirdiği bir çok fetihlerle devletin sınırlarını Atlas Okyanusu'na kadar ulaştırmış ve Akdeniz'deki bazı önemli adaları fethetmiştir. Tanca valisi Târık b. Ziyâd'la birlikte üç yıl gibi kısa bir süre içinde jeopolitik açıdan çok önemli bir ülke olan ve Müslümanların Avrupa'ya geçiş noktasında bulunan İspanya'yı (Endülüs) fethetmiştir, Mûsâ b. Nusayr'ın gerek halife Velîd b. Abdülmelik, gerekse ondan sonra halife olan Süleyman b. Abdülmelik'le olan ilişkileri ve âkıbeti oldukça ilginçtir. Bu makalede Mûsâ b. Nusayr'ın hayatı, fetih hareketleri kısaca ele alındıktan sonra Velîd b. Abdülmelik ve Süleyman b. Abdülmelik'le olan ilişkileri, âkıbeti ve bu fâtih komutana revâ görülen bazı uygulamalar incelenip değerlendirilecektir.

Anahtar Kelimeler: Mûsâ b. Nusayr, Endülüs, Endülüs'ün fethi, Mûsâ b. Nusayr'ın akıbeti.

\section{Giriş}

Askerî, siyâsî, dinî, sosyal, iktisâdî ve kültürel açılardan çeşitli sonuçlar doğuran İslâm fetihlerinin ve fetih siyâsetinin oluşumunda ilk dönem İslâm tarihinin önde gelen fâtih komutanlarının faaliyetleri büyük önem taşımaktadır. Mûsâ b. Nusayr (19-97/640-716) da İslâm tarihinin ilk asrında yaşamış önemli komutan ve valilerden birisidir. O, Emevîler döneminde vali olarak tayin edildiği Ifrîkıyye ve Mağrib bölgesinde gerçekleştirdiği bir çok fetihlerle devletin s1nırlarını Atlas Okyanusu'na kadar ulaştırmış, Akdeniz'deki bazı önemli adaları ele geçirmiştir. Azatlısı ve Tanca valisi Târık b. Ziyâd'la birlikte üç yıl gibi kısa bir süre içinde İslâm tarihinde ilk defa jeopolitik açıdan çok önemli bir ülke olan ve Müslümanların Avrupa'ya geçiş noktasında bulunan İspanya'yı (Endülüs) fethederek burada asırlar boyunca İslâm dininin egemen olmasını ve Endülüs kültür ve medeniyetinin doğmasını sağlamıştır.

Mûsâ b. Nusayr'ın gerek Velîd b. Abdülmelik, gerekse ondan sonra halife olan Süleyman b. Abdülmelik'le olan ilişkileri ve âkıbeti oldukça ilginç bir gelişme takip etmiştir. Mûsâ b. Nusayr'ın fetih sonrasında halife Velîd b. Abdülmelik ve Süleyman b. Abdülmelik'le ilişkileri ve akıbeti hakkında tarihçiler birbirinden farklı, zıt ve karışık bilgiler vermektedirler. Çağdaş araştırmalarda ise fazla üzerinde durulmadan kısaca temas edilip geçilen bu konunun araştırılıp tahlil edilmesine ihtiyaç hissedilmektedir. 
Bu makalede Mûsâ b. Nusayr'ın hayatı, fetih hareketleri kısaca ele alındıktan sonra Velîd b. Abdülmelik ve Süleyman b. Abdülmelik'le olan ilişkileri, âkıbeti ve bu fâtih komutana revâ görülen bazı uygulamalar incelenip değerlendirilecektir. $\mathrm{O}$, kendisine yıllardır destek olan işbaşındaki halife Velid'in emrine uyarak hızlı bir şekilde hilafet merkezine dönüp Endülüs'ün fethinin ganimetlerini halifeye teslim ederek vefalı bir Müslüman komutan portresi çizmiştir. O'na acele etmemesini, Şam’a gelişini geciktirmesini haber gönderen veliahd Süleyman b. Abdülmelik'in sözünü tutmadığ1 için de ileride sıkıntılı günler yaşayacaktır.

\section{1- Mûsâ b. Nusayr'ın hayatı ve fetih hareketlerine genel bir bakış}

Tam ismi Mûsâ b. Nusayr b. Abdurrahman b. Zeyd'dir. Kaynaklarda künyesi "Ebû Abdirrahman" olarak geçmektedir. ${ }^{1}$ Mûsâ b. Nusayr, Hz. Ömer' in hilâfeti zamanında 19/640 yılında doğmuştur. ${ }^{2}$ Gerek temel kaynaklarda, gerekse çağdaş araştırmalarda genel olarak kabul edilen husus, Mûsâ b. Nusayr'ın Lahm kabilesine mensup olduğu veya bu kabilenin azatlısı olduğudur. Ayrıca o, hayatının ilerleyen yıllarında Ümeyyeoğullarının hizmetinde harac görevlisi, komutan ve vali olarak görev aldığı için bazı kaynaklarda Ümeyyeoğullarının azatlısı olarak ifade edilmiştir. Mûsâ b. Nusayr'ın babası olan Nusayr Hıristiyan birisiydi. Hz. Ebûbekir döneminde İslâm komutanı Hâlid b. Velid'in fetih hareketleri sırasında ele geçirildi. Nakledildiğine göre Hâlid b. Velid, 12/633 yılında Aynu't-Temr ${ }^{3}$ kalesini kuşatmış ve yapılan savaş sonunda kaleyi fethetmişti. Buradaki bir kilisede İncil okuyan 40 kişilik grubu esir almıştı. İşte Nusayr da bu esirler arasındaydı. Nusayr'ın asıl ismi Nasr idi, küçültme (tasgîr) şeklinde "Nusayr" denildi. ${ }^{4}$

1 Humeydî, Cezvetü'l-Muktebis, s. 317: İbn Hazm, Cemheratu Ensâbi'l-Arab, s. 430; İbn Hallikân, Vefeyâtu'l-A'yân, V, s. 318; Ziriklî, Hayruddin, el-A'lâm, VIII, 285. Mûsâ b. Nusayr'ın hayatı, fetihleri ve kişiliği hakkında geniş bilgi için bkz: Atçeken, İsmail Hakkı, Endülüs'ün Fethi ve Mûsâ b. Nusayr, Ankara, 2002.

2 Yafiî, Mir'âtü'l-Cinân, I,s. 144; İbn Kesîr, el-Bidâye ve'n-Nihâye, IX,s. 171; Makkarî, Nefhu't-Tîb min Ğusni'l-Endelüsi'r-Ratîb, I, s. 269.

3 Aynu't-Temr: Kûfe'nin batısında Enbâr şehrine yakın bir beldedir. Bkz: Yâkût elHamevî, Mu'cemü'l-Büldân, IV, s. 199 ; Mustafa Fayda, Allah'ın Kılıcı Hâlid b. Velid, s. 344.

4 Belâzurî, Fütûhu'l-Büldân (Ülkelerin Fethi), çev: Mustafa Fayda, s.353-354; Taberî, Târîhu'l-Ümemi ve'l-Mulûk, IV, s. 193; Ahbâru Mecmû'a fí Fethi'l-Endelüs ve Zikri Ümerâihâ, (Müellifi meçhul), s. 14 ; İbnü'l-Esîr, el-Kâmil fi't-Târîh, II, s. 395; Stephen Ronart, "Mûsa İbn-Nusayr", CEAC, s. 394. 
Babası Nusayr azad edildikten sonra Mûsâ, Şam'da Arap muhitinde yetişti. Arap âdet ve geleneklerini öğrendi. ${ }^{5} \mathrm{Hem}$ babası Nusayr, hem de bizzat kendisi Emevîler'in hizmetinde çalıştı. Mûsâ, babası Nusayr'ın ölümünden sonraki dönemde Muâviye'nin maiyyetinde bulunan gençlerden birisiydi. Muâviye'nin Hz.Osman döneminde 27/647 yılında fethettiği Kıbrıs adasına sonraki yıllarda seferler devam eden seferlere Mûsâ b. Nusayr da katıldı. Emeviler döneminde Muaviye b. Yezid'in ölümünden sonra meydana gelen Mercu Râhıt Savaşı sonunda Dahhak b. Kays mağlup olup öldürülünce Mûsâ b. Nusayr Misır'a gitti ve orada bulunan Abdülazîz b. Mervân'a sığındı. Mûsâ b. Nusayr, Mervân b. Hakem ve ondan sonra halife olan Abdülmelik b. Mervân (halifeliği 65-86/685-705)'ın halifelik yıllarında Mısır'da bulunuyordu. Abdülmelik b. Mervân, kardeşi Bişr b. Mervân'1 Irak'a vali olarak tayin edince onun yanına danışman ve yardımcı olarak olarak Mûsâ b. Nusayr' 1 da gönderdi. ${ }^{6}$

Mûsâ, bir süre Basra'da kaldıktan sonra Abdülazîz b. Mervân'la birlikte Mısır'a gitti ve bundan sonraki hayatı Misır'da devam etti. Mûsâ b. Nusayr'ın Ifrîkıyye ve Mağrib valiliğine tayin edilmesi olayının tarihi konusunda genelde tercih edilen yıl 86/705 yılıdır. ${ }^{7}$ Bu yıl aynı zamanda Abdülmelik b. Mervân'ın ölüp yerine Velîd b. Abdülmelik'in halife olduğu yıldır. Mûsâ b. Nusayr Abdülmelik b. Mervân'ın son aylarında vali olarak tayin edilmiş ve ondan sonra işbaşına gelen Velîd b. Abdülmelik tarafından valiliği onaylanmıştır.

Mağrib bölgesine Mûsâ b. Nusayr'dan önce on tane komutan tayin edilmişti. Mûsâ b. Nusayr, Emevîler döneminde bu bölgeye tayin edilen en muktedir vali-komutanlardan birisidir. Mûsâ'nın tayini Ifrîkıyye ve Mağrib'deki fetih merhalelerinden önemli bir merhaledir. Bu merhale istikrar ve genişleme merhalesidir. ${ }^{8}$ Gerçekten de Mûsâ'nın valiliği döneminde daha önceden yapılan fetihlere ilaveler yapılmış, Mağribu'l-Aksâ bölgesinin fethedilmesiyle Mağrib fetihleri tamamlanmıştır. Önceki yıllarda fethedilmiş bölgelerdeki isyan girişimleri bastırılmış ve iç istikrar sağlanmıştır. Öte yandan

Mevsûatu Târîhi'l-Mă̆ribi'l-Arabî, I, s. 134.

el-İmâme ve's-Siyâse (İbn Kuteybe'ye nispet edilmektedir), s. 226; M.Mâhir Hammâde, el-Vesâiku's-Siyâsiyye ve'l-İâriyye li'l-Asri'l-Ümevî, s. 297; Câsim elUbûdî, "Mûsâ b. Nusayr", DİA, XXXI, s. 224.

7 Hâlid es-Sûfî, Târîhu'l-Arab fi'l-Endelüs, s. 44.

8 Mevsûatu Târihi'l-Mağribi'l-Arabî, I, s. 135. 
Akdeniz'deki önemli bazı adalara deniz seferleri düzenlenmiş ve bunlardan bir kısmı fethedilmiştir.

Daha önce Hassan b. Nu'man'ın valiliği zamanında fethedilen Zağvan ${ }^{9}$ ve civarı, Mûsâ b. Nusayr'ın valiliği sırasında ilk ele geçirilen yerdir. Zağvan'ın ele geçirilip isyancılar etkisiz hale getirildikten sonra Mûsâ b. Nusayr, Ifrîkıyye'de isyan eden diğer bölgeler üzerine kendi oğulları Abdurrahman, Abdullah ve Mervân'ı gönderdi. Bunlar gittikleri bölgeleri yeniden İslâm hâkimiyeti altına soktular, bir çok ganimet ve esirle geri döndüler. Mûsâ'nın oğullarının kazandıkları fetihler sonucu binlerce esirle geri döndükleri nakledilir. Mûsâ'nın valiliği sırasında Ifrîkıyye bölgesinde 300.000 esir ele geçirildiği ve bunun beytülmâle ait hisse olan humus'unun 60.000 olduğu ifade edilir. ${ }^{10}$

Hevvâre, Zenâte ve Kutâme Berberîlerinin ikâmet ettiği şehirlerden birisi olan Sicilmâse ${ }^{11}$ şehri ve civarına fethedildi Kayravan'da yerine vekil olarak oğlu Abdullah b. Mûsâ'yı bırakan Mûsâ, 10.000 kişilik ordusuyla Mağribu'l-Evsat'taki Secûma şehri üzerine yürüdü. Secûma meliki Küseyle b. Lemzem öldürüldü. Nakledildiğine göre 100.000 esir elde edildi. ${ }^{12}$ Berberîlerin bir kısmı Araplardan çekinerek Mağrib'in uç noktalarına kaçmışlardı. Mûsâ b. Nusayr hem bu kaçan Berberîleri takip etmek, hem de Mağribu'1Aksâ bölgesini İslâm hâkimiyeti altına almak için 87/706 yılında harekete geçti. Öncelikle oğlu Mervân b. Mûsâ'yı Sûsu'l-Aksâ ${ }^{13}$ üzerine gönderdi. Sûsu'l-Aksâ fethedildi. Bu fetihle ele geçen esir sayısı 40.000'e ulaştı. ${ }^{14}$ Ifrîkıyye ve Mağrib fetihlerinde İslâm ordusunda sadece Arap askerler değil, yoğun bir şekilde Berberîler de bulunuyordu. Mağribu'l-Aksâ bölgesindeki fetihlerde Mûsâ b. Nusayr'ın

9 Zağvan: Tunus'un kıble cihetinde dağlık bir bölgeye verilen isimdir. Aynı adlı bir de kalesi mevcuttur. Bkz: Yâkût el-Hamevî, III, s. 162.

10 el-İmâme ve's-Siyâse, s. 229; İbnü'l-Esîr, IV, 540 ; İbn Izârî, I, 40 ; Nüveyrî, XXIV, s. 39; İ̉n Haldûn, IV, s. 239.

11 Sicilmâse: Mağrib'in güneyinde Sûdan civarında ve Fas'a on günlük mesafede olan bir şehirdir. Bkz: Istahrî, Mesâliku'l-Memâlik, s. 37, 39; Yâkût el-Hamevî, III, s. 217.

12 el-imâme ve's-Siyâse, s. 232-233; İbn Izârî, I, s. 41.

13 Sûsu'l-Aksâ: Mağrib'de başkenti Tarkele olan bir bölgedir. Sûsu'l-Ednâ ile arasındaki mesafe yürüyüşle iki ay kadardır. Bkz: Yâkût el-Hamevî, III, s. 319.

14 el-İmâme ve's-Siyâse, s. 235; İbnü'l-Esîr, IV, s. 540. 
azatlısı olan Berberî asıllı Târık b. Ziyâd ${ }^{15}$ öncü birliklerin komutanı olarak görev yapıyordu. Daha sonraki yıllarda Endülüs'ün fethi s1rasında isminden sıkça bahsettirecek olan Târık b. Ziyâd, Mağribu'1Aksâ bölgesinde de faydalı hizmetlerde bulundu ve Mûsâ b. Nusayr'a yardımcı oldu. Mûsâ b. Nusayr, Tanca ${ }^{16}$ şehri ve civarını 89/708 yılında fethetti ve Tanca valiliğine azatlısı Târık b. Ziyâd'ı tayin etti. Onun yanına 17.000 Arap ve 12.000 Berberî asker bıraktı.

Daha önceki dönemlerde Antakya, Kayseriyye, Askalan gibi limanları ele geçiren Müslümanlar buralarda gemi yapım işine önem verdiler. ${ }^{17}$ Mûsâ b. Nusayr ise bu limanlardan uzak bir mesafede bulunan Tunus bölgesinde gemi yapımı için bir tersane kurmaya karar verdi. Tersanenin inşâsı tamamlanınca orada 100 tane gemi yapılmasını istedi. Mûsâ, Sicilya adası üzerine birkaç sefer düzenledi. Her ne kadar büyük bir ada olan Sicilya'nın tamamı fethedilmemiş olsa da, bu adaya ait Uliyye ve Saragosa fethedilmiştir. Sardunya ${ }^{18}$ adası da Mûsâ b. Nusayr tarafından fethedildi. Akdeniz'de İspanya'ya yakın iki küçük ada olan Mayorka ${ }^{19}$ ve Minorka ${ }^{20}$ ile civardaki irili ufaklı adalara genel bir ifade olarak "Malyâr adaları" ismi verilmektedir. ${ }^{21}$ Mayorka ve Minorka adaları İspanya ile Sicilya adası arasındadır. Nakledildiğine göre Mûsâ b. Nusayr bizzat 89/707-708 yılında bu adalara sefer düzenlemiş ve bunları fethetmiştir. ${ }^{22} \mathrm{Bu}$ deniz seferine Müslümanların ileri gelenlerinden bir çok kimsenin katılması sebebiyle İslâm tarihinde "Ğazvetü'l-Eşrâf" adı verilmiştir. ${ }^{23}$

Mağribu'l-Aksâ fetihlerini tamamlayan Mûsâ, halife Velid'den izin alarak Endülüs'ün fethine yöneldi. 91/710 yılında Berberî asıllı

15 Târık b. Ziyâd hakkında fazla bilgi için mesela bkz: Himyerî, er-Ravdu'l-Mi'târ fi Haberi'l-Aktâr, s. 35; Makkarî, I, s. 254; Salih Kaymakçı, Târık b. Ziyâd Hayatı ve Şahsiyeti (Basılmamış Yüksek Lisans Tezi, Konya, 2000), s. 12-19 vd.

16 Tanca: Mağribu'l-Aksâ şehirlerinden birisidir. Septe (Ceuta) şehri ile arasındaki uzaklık 30 mil veya bir günlük mesafedir. Bkz: Yâkût el-Hamevî, IV, s. 49; Himyerî, s. 395-396.

17 Hüseyn Mu'nis, Târîhu'l-Müslimîn fî Bahri'l-Mütevessit, s. 46.

18 Sardunya: Akdeniz'de Cezâyir'in karşısında bulunan büyük bir adadır. Bkz: İbn Hurdâzbih, s. 109; Yâkût el- Hamevî, III, s. 236.

19 Mayorka: Endülüs'ün doğusunda bulunan ve Minorka adasına yakın olan bir adadır. Bkz: Yâkût el-Hamevî, V, s. 285.

20 Minorka: Endülüs'ün doğusunda bulunan ve Mayorka adasına yakın olan bir adadır. Bkz. Yâkût el-Hamevî, V, s. 251.

21 Bkz: Nadir Özkuyumcu, s. 189-dipnot: 297.

22 el-imâme ve's-Siyâse, s. 236.

23 Zehebî, Târîhu'l-İslâm (H. 81-100), s. 34; Sûyûtî, s. 224. 
Tarîf b. Mâlik komutasında küçük bir birliği keşif için İspanya'nın güneyine gönderdi. Ertesi yıl (92/711)Berberî asıllı Târık b. Ziyâd'1 7.000 kişilik bir ordu ile İspanya'nın fethi için görevlendiren Mûsâ b. Nusayr, daha sonra Târık'ın ek yardım kuvveti istemesi üzerine 5.000 kişilik bir askerî birliği de göndermişti. Târık, Endülüs'teki fetihleriyle ilgili sorumlu ve bağlı olduğu Mûsâ'ya bilgi veriyordu. Târık bir yıl içinde bazı fetihlerde bulunmuştu ancak daha fethedilecek önemli şehirler ve bölgeler mevcutttu. Fetihleri tamamlamak ve fetih sonrası ülkedeki idârî düzenlemeleri gerçekleştirmek amacıyla Mûsâ b. Nusayr Endülüs'e geçmek için harekete geçti.

Mûsâ b. Nusayr, 93/712 yılında 18.000 askerle geçtiği Endülüs'te Septe Kontu Julianus ve rehberlerin gösterdiği İspanya'nın batı bölgelerinden başlayarak kuzey bölgelerine doğru sefere başladı. Günümüzde Cebel-i Mûsâ diye bilinen bölgeden yola çıkan Mûsâ, Şezûne sahiline ulaştı ve Şezûne (Medina Sidonia) şehrini kuşattı. Bu şehir savaş yapılarak fethedildi. Neticede şehir halkı Mûsâ'ya teslim oldu. Bu fetih sonucu çok miktarda ganimet elde edildi. ${ }^{24}$ Karmûne (Carmona), Endülüs'ün en müstahkem ve en sağlam kalesi olan şehirlerinden birisiydi. İşbiliyye (Sevilla) şehrinin doğusunda bulunan bu şehir Mûsâ b. Nusayr'ın fethettiği ikinci şehirdir. Şehir baştan başa sağlam surlarla çevriliydi. Mûsâ, Karmûne şehrine yürüdü ve burasını kuşattı. Bu şehrin, Endülüs şehirleri arasında ele geçirilmesi en zor olanı olduğu nakledilir. ${ }^{25}$

Mûsâ'nın Endülüs'teki fetihleri husunda bir değerlendirmede bulunan Hüseyn Mu'nis'e göre, bu fetihler sayesinde Müslümanların Cezîretü'l-Hadrâ' dan Kurtuba'ya kadar devam eden güzergahları emniyet altına alınmış oldu. ${ }^{26}$ Böylece Cezîre, Şezûne, Ra'vak, Karmûne, İstece, Kurtuba şehirleri ve kaleleri Müslümanların eline geçmiş oldu. Mûsâ b. Nusayr bundan sonra İberya yarımadasının Tuleytula (Toledo)'dan sonra ikinci büyük merkezi olan İşbiliyye (Sevilla) şehrini fethetmek için batıya yönelme imkanı buldu. Mûsâ'nın bu fetihleri sayesinde İslâm ordularının esas güzergahını oluşturacak ve sonraki yıllarda yapılacak fetihlere zemin hazırlayacak bir güzergah kurulmuş oldu. İşbiliyye şehri İspanya'nın en büyük ve en önemli şehirlerinden birisidir. Burası büyüklüğünün yanısıra tarihî eserleri ve ilginç binaları açısından İspanya'nın en önemli merkezlerinden birisidir.

\footnotetext{
İbnü'l-Kûtiyye, s. 77; Ahbâru Mecmû'a, s. 24; Makkarî, I, s. 257.

İbnü'l-Esîr, IV, s. 564 ; Makkarî, I, s. 257.

Hüseyn Mu'nis, Fecr, s. 90-91.
} 
Karmûne'yi fetheden Mûsâ b. Nusayr, daha sonra Târık b. Ziyâd'ın takip ettiği yolun batısındaki İşbiliyye (Sevilla) şehrine yürüdü. Nakledildiğine göre bu şehri kuşatan Mûsâ ve ordusu birkaç aylık kuşatmadan sonra bu şehri fethettiler. Mûsâ b. Nusayr fetihten sonra İşbiliyye halkına ve orada bulunan Yahudilere karşı hoşgörülü davrandı, onlara kucak açtı. Nakledildiğine göre Mûsâ, İşbiliyye şehrine Yahudileri yerleştirdi. ${ }^{27}$

Mûsâ b. Nusayr, İşbiliyye'yi fethettikten kısa bir süre sonra Mâride şehrine doğru yöneldi ve orasını fethetti. Bu şekilde Mûsâ b. Nusayr Endülüs'e geçtikten sonra Şezûne, Karmûne, İşbiliyye, Mâride, Niebla, Bace, Mursiyye vb. şehirleri fethetmiş, oğlu Abdülazîz b. Mûsâ vasıtasıyla İşbiliyye'de çıkan isyanı bastırarak ikinci defa ele geçirmiştir. Sadece Târık b. Ziyâd'ın daha önce fethetmediği şehirleri fethetmekle kalmamış, Endülüs'teki fetih hareketlerinin istikrara kavuşması ve tamamlanması için önemli bir adım atmıştır. İslâm ordusunun gücünü bir kez daha düşmanlara göstererek bölgede Müslümanların otoritesini güçlendirmiştir.

\section{2- Endülüs'ün Fethi Sonrası Mûsâ b. Nusayr}

Endülüs'ün kuzey bölgelerinde ve Fransa topraklarında fetihlere devam eden Mûsâ b. Nusayr'ın yanına halife Velîd b. Abdülmelik'in elçisi Muğîs er-Rûmî gelip onun Şam'a geri dönme emrini getirdi. Mûsâ, Endülüs'te fethetmediği tek bir bölge olan kuzeydeki Cillîkıyye (Galicia) bölgesini fethetmek için Muğîs'ten biraz süre istemişti. Bu bölgede fetihlere devam eden Mûsâ'nın yanına halife Velîd'in ikinci elçisi gelmişti. Ebû Nasr isimli bu elçi, Mûsâ b. Nusayr'ın bindiği hayvanın yularından tutup onu o bölgeden çıarmak istedi. Bu ikinci elçinin geldiği yer Cillîkıyye'nin Lugo şehriydi. ${ }^{28}$ Halife Velîd'in ısrarlı davetine karşın daha fazla bekleyemeyeceğini gören Mûsâ b. Nusayr Endülüs'ten ayrılmaya karar verdi. Yola çımadan önce Endülüs'te bazı idârî düzenlemeler yapan Mûsâ, oğlu Abdülazîz b. Mûsâ'yı Endülüs valiliğine tayin etti, başkent olarak İşbiliyye (Sevilla) şehrini seçti. Burası herhangi bir tehlike anında Müslümanların gemileriyle ulaşabilecekleri bir yerdi. Mûsâ b. Nusayr, İşbiliyye şehrinin Endülüs'ün giriş kapısı olmasını istedi. ${ }^{29}$

Endülüs'ün fethi sonrasında Mûsâ b. Nusayr'ın Velid b. Abdülmelik ve daha sonra halife olacak olan Süleyman b. Abdülmelik'le

\footnotetext{
27 İbnü'l-Esîr, IV, s. 564; Makkarî, I, s. 257.

28 İbnü'l-Esîr, IV, . s. 566; Nüveyrî, XXIV, s. 51-52 ; Makkarî, I, s. 263.

29 Ahbâru Mecmû'a, s. 27; Makkarî, I, s. 263.
} 
ilişkileri önem arzetmektedir. Mûsâ b. Nusayr'ın akıbeti ve ömrünün son dönemlerinde başına gelen ilginç hadiseleri iyi tahlil edebilmek için bu iki halifeyle olan ilişkilerinin objektif ve dikkatli bir şekilde incelenmesi gerekmektedir. Bu konuda birbirinden farklı ve zıt nakillerin olması, kimi çağdaş araştırmacıların bile meseleye ön yargılı ve tek bir noktadan yaklaşımları bizim bu konuları ayrı ayrı ele almamızı gerektirdi. Bazı noktaların aydınlatılabilmesi için kaynaklarda karışık bir şekilde verilen bu ilişkilerin detaylı bir şekilde araştırılmasının önemli olduğu kanaatindeyiz.

\section{a- Velîd b. Abdülmelik-Mûsâ b. Nusayr İlişkilerinin Tahlîli}

Mûsâ b. Nusayr Abdülmelik b. Mervan'ın son dönemlerinde vali olarak atandığı Ifrîkıyye ve Mağrib bölgesinde kısa bir süre içinde isyan eden Berberî kabilelerini tekrar itaat altına almış, bölgede önemli fetihler gerçekleştirmiş ve sayıları yüz binlerle ifade edilen esirler elde etmiştir. Bu olumlu gelişmeler Abdülmelik b. Mervân'ın hoşuna gitmiş ve Mûsâ'dan memnuniyetini bildirmiştir. 86/705 y1lında Abdülmelik b. Mervân'ın ölümü üzerine halife olan Velîd b. Abdülmelik, Mûsâ $b$. Nusayr'ın valiliğe devam etmesini isteyerek onun valiliğini onaylamıştır. ${ }^{30}$ Ayrıca Velîd, Ifrîkıyye ve Mağrib bölgesini Mısır'a bağlı olmaktan çıkarmış ve bağımsız bir valilik haline getirmiş̧tir. Bu uygulamayla bundan sonra bu bölge valileri doğrudan doğruya Şam'daki halifeye karşı sorumlu olacaklardı. Velîd b. Abdülmelik bu kararıyla daha önce valiler arasında meydana gelen bazı anlaşmazlıkları ve yetki kargaşasını önlemiştir.

Mûsâ b. Nusayr, Velîd b. Abdülmelik'in 10 yıllık halifeliği boyunca (86-96/705-715) aralıksız bu görevini sürdürmüştür. Halife Velîd ile Mûsâ'nın ilişkilerinin daha başlangıçtan itibaren iyi bir durumda olduğu görülmektedir. Valiliğe atandığı dönemden itibaren Mûsâ, halife velid ile haberleşmesini devam ettirmiş, Mağrib bölgesinde fetihleri ve gelişmeleri bazen mektup, bazen de elçiler göndererek hilafet merkezine ulaştırıyordu. Bu fetih haberlerini öğrenen Velîd son derece seviniyor ve Allah (cc)'a hamdediyordu..$^{31}$ Bir diğer nokta Mûsâ b. Nusayr'ın fetih hareketleri halife Velîd tarafından sürekli olarak destekleniyordu. Çünkü Velîd Horasan bölgesi ile Mağrib bölgesine özel önem gösteriyordu. O'nun teşvikleriyle doğuda Kuteybe b. Müslim, batıda Mûsâ b. Nusayr zaferden zafere koşuyordu. Bu fetihlerde komutanların tecrübesinin yanısıra halife ile bu

30 İbn Izârî, I, s. 41.

31 el-İmâme ve's-Siyâse, s. 236. 
komutanlar arasındaki iyi ilişkiler ve uyumun da önemli rol oynamiştır.

Mağribu'l-Aksâ'daki fetihleri tamamlayan Mûsâ, Emevî devletinin batı sınırlarını Atlas Okyanusu kıyılarına kadar ulaştırmıştır. Bundan sonraki hedefi Endülüs'ü fethetmekti. Bu düşüncesi hakkında Velîd'in fikrini almak için ona mektup gönderdi. Velîd, denizde oluşabilecek felaketlerinden bahsederek dikkatli davranmasını istedi. Mûsâ b. Nusayr, geçilecek yerin bir boğaz olduğunu ve karşı tarafın uzaktan gözle göründüğünü haber verince halife Velîd önce bir deneme seferinin gönderilmesini istedi. Mûsâ da bu emre uyarak Tarîf b. Mâlik'i deneme amacıyla Endülüs'e gönderdi. Tarîf başarılı bir şekilde ve ganimetler elde ederek dönünce Mûsâ, Târık b. Ziyâd'1 92/711 yılında 7.000 kişilik orduyla Endülüs'e gönderdi. Görüldüğü gibi Mûsâ b. Nusayr, Endülüs'ün fethi öncesi Velîd b. Abdülmelik ile en az iki defa haberleşerek halifenin iznini ve onayını almıştır. Mûsâ, Mağrib bölgesinde başına buyruk hareket etmemiş ve halife ile iletişime önem vermiş, gelişmelerden hilâfet sarayını haberdar etmiştir. Halifenin ona güvenmesi ve Mûsâ'nın da halifeyle sürekli iletişim halinde olması on yıl boyunca kesintisiz valiliğe devam etmesinde önemli pay sahibidir.

Öte yandan Endülüs'ün fethi için gönderilen Târık b. Ziyâd, buradaki fetih hareketlerini Mûsâ b. Nusayr'a haber veriyor, Mûsâ da halife Velîd'e ulaştırıyordu. Dolayısıyla Mağrib bölgesi fetihlerinden sonra Endülüs'teki fetihlerde de hilâfet merkeziyle iletişim devam etmiştir. Sadece Târık, Lekke vadisi savaşından sonra askerî faaliyetlerin yoğunluğu nedeniyle bir müddet efendisi Mûsâ'ya mektup göndermemiştir. Târık b. Ziyâd'dan bir yıl sonra Mûsâ, 93/712 yılında 18.000 kişilik ordusuyla Endülüs'e geçmiş ve bazı önemli şehirleri fethettikten sonra Tuleytula'da Târık ile buluşmuştur. Az sayıdaki bazı tarihçiler bu buluşma sonrasında Mûsâ'nın Târık'1 hapsettiği kanaatindedirler. Çağdaş araştırmacılarla birlikte bizim de doğru olarak kabul edemediğimiz bu görüşe göre; bu olayı öğrenenen halife Velîd, Mûsâ'ya kızmış ve ona gönderdiği elçisiyle Târık'ın serbest bırakılmasını istemiştir. Bunun üzerine Mûsâ, Târık'ı serbest bırakmış ve komutanlık görevine iade etmiştir. ${ }^{32}$ Ancak bu konu tartışmalı bir konudur ve bu rivâyete diğer tarihçiler ilgi göstermemişlerdir. Öte yandan Velîd'in azatlısı ve elçisi Muğîs er-Rûmî, Mûsâ b. Nusayr'ın valiliğini ve başarılarını hazmedemi-

32 İbn Abdülhakem, s. 210. 
yordu. Muğîs, Şam'a gittiğinde Mûsâ ile Tarık arasındaki anlaşmazlığı abartarak anlatmıştı. Her fırsatta Mûsâ'yı kötüleyerek halife Velîd'in gözünden düşürmeye çalışıyor, Şam'da Mûsâ aleyhine bir hava oluşturmaya gayret ediyordu. ${ }^{33} \mathrm{Bu}$ dedikodular ve abartılı sözler Mûsâ ile yıllardır yüzyüze görüşmeyen ve olayları daha çok tek taraflı dinlemek zorunda kalan halife Velîd'i ister istemez etkiliyordu.

Mûsâ b. Nusayr, Endülüs'ün kuzeyinde eksik kalan fetih hareketlerini tamamlamaya çalışırken halife Velîd tarafından önce Muğîs er-Rûmî, daha sonra da Ebû Nasr isimli elçi gönderilerek Mûsâ'nın Şam'a derhal geri dönmesi emredildi. Bunun sebebi olarak Mûsâ'nın, Endülüs'e gitmesinden sonra Ifrîkıyye valiliğinden ayrılıp oraya yerleşeceği ve bağımsız hareket edeceği şeklinde Şam'da yayılan bir dedikodu zikredilir. Buna göre Velîd'in çevresinde bulunan ve Mûsâ b. Nusayr'a muhâlif oldukları anlaşılan bazı kişiler, Mûsâ hakkında dedikodu yaparak onun Endülüs'e yerleşeceğini ve o bölgenin nimetlerinden istifade edeceğini söylediler. Bu sırada Mûsa fetihlerle uğraştığ 1 için halifeye mektup yazmakta biraz gecikmişti. Nakledildiğine göre bu gerçek dişı sözler ve dedikodulardan etkilendiği anlaşılan Velîd b. Abdülmelik, Şam'daki kadıya namaz sırasında Mûsâ b. Nusayr'a beddua etmesini bile emretmişti. Mûsâ, Tuleytula'ya girdikten sonra Ali b. Rebah başkanlığında bir heyeti Şam'a göndermişti. Şam'a gelen Ali b. Rebah burada kadının Mûsâ b. Nusayr'a bedduasını işitince çok şaşırmış ve şöyle demişti: “Allah Allah! Mûsâ'ya dua etmek gerekir. Allah (cc)'a yemin olsun ki, o elini itaatten geri çekmemiştir, cemaatten de ayrılmamıştır. Ben onun yanından geliyorum ve onunla ilgili haberlerim var" dedi. Bunun üzerine Velîd, Ali b. Rebah'ı huzuruna çağırdı ve: "Arkanda ne var?" diye sordu. Ali b. Rebah: "Ey Mü'minlerin emîri! Arkamda hepsi hoşlanılacak, sevinilecek şeyler var. Mûsâ b. Nusayr'ı Endülüs'te bıraktım. Allah (cc) orada ona zafer nasip etti. Allah (cc) onun eliyle başka hiçbir kimsenin daha önce fethetmediği yerleri fethettirdi. $\mathrm{O}$, yanındaki ileri gelen bazı kişilerle birlikte beni size elçi olarak gönderdi" dedi. Mûsâ'nın gönderdiği mektubu okuyan Velîd şükür secdesine kapand1. ${ }^{34}$ Görüldügü gibi yanlış anlaşılma ve saray dedikoduları sebebiyle halife Velid, Mûsâ hakkında olumsuz bir kanaate sahip olmuş ancak Mûsâ' nın gönderdiği heyet Şam'a ulaşıp gerçek haberleri verince durum düzelmiştir.

33 Hüseyn Mu'nis, Fecr, s. 85-86.

34 el-İmâme ve's-Siyâse, s. 239. 
Bu konudaki farklı bir rivâyete göre; Mûsâ b. Nusayr'ın Fransa topraklarına girip bazı şehirleri fethetmesi, tüm batı Avrupa'yı fethedip İstanbul'a ve oradan da hilâfet merkezi olan Şam'a ulaşma projesini öğrenen Velîd, Mûsâ'yı geri çağırmaya karar verdi. Müslüman askerlerini Fransa topraklarına sürüklediği ve bu hususta kendisinin iznini almadığı gerekçesiyle Velîd'in Mûsâ'yı geri çağırdığı belirtilir. ${ }^{35}$ Mûsâ'nın batı Avrupa üzerinden İstanbul'a ve oradan da Şam'a ulaşma isteğinin halife Velîd'i endişelendirdiği anlaşılmaktadır. Mûsâ b. Nusayr fetihlere devam ettiği için ilk gelen elçiyi biraz oyalamıştı. Sonradan ikinci elçi gelince Endülüs'ten ayrılmaya karar verdi. Uzun yıllar iyi ilişkiler içinde olduğu halife Velid'le olan ilişkilerini fazla bozmak istemediği için böyle davrandığı düşünülebilir.

Mûsâ b. Nusayr dönüş hazırlıklarına başlamıştı. Aslında Velîd b. Abdülmelik' in emri gelmeseydi bir süre daha Endülüs'te kalmayı arzu ediyordu. Her ne kadar fetihleri büyük ölçüde tamamlamış olsa da, bazı idârî düzenlemeler ve diğer faaliyetler açısından biraz daha zamana ihtiyacı vardı. Mûsâ, Cillîkıyye'den yola çıkarak İşbiliyye şehrine geri geldi. Târık b. Ziyâd da yukarı bölgelerden yola çıkarak Mûsâ'ya yetişti. Mûsâ b. Nusayr'ın Şam'a dönüş kervanında Târık b. Ziyâd, Muğîs er-Rûmî, Hubeyb b. Ukbe b. Nâfi el-Fihrî de vardı. Ayrıca Endülüs'ün fethinde bulunan tâbiinden bazı kimseler ve Şam'a geri dönmek isteyen kişiler de Mûsâ ile yola çıkmışlardı. ${ }^{36}$ Mûsâ'nın geri dönüş kervanında ele geçirilen pek çok ganimet, esirler, çeşitli mücevherler, Hz. Süleyman'a ait olduğu bildirilen masa ve benzeri görülmemiş mallar vardı. Yine Frank meliklerinin oğulları, Kurtuba emîri, Sûs emîri, Ersaf kalesi emîri, Mayorka emîri ve Endülüs emîrlerinden 100 kişi de Mûsâ b. Nusayr'la birlikte idiler. ${ }^{37}$ Nakledildiğine göre ganimetleri ve hazineleri taşımak için hayvanlara çektirilen 30 tane araba yaptırılmıştı. Bu arabalara altın, gümüş ve mücevherler yüklenmişti. ${ }^{38}$

Mûsâ b. Nusayr ve beraberindekiler 95/714 yılı Ramazan Bayramından sonra İşbiliyye şehrinden yola çıktılar. ${ }^{39}$ Endülüs'ten ayrılıp deniz yoluyla kuzey Afrika'ya geçtiler ve Kayravan şehrine

\footnotetext{
İbnü'l-Kûtiyye, s. 192-193; İbn Haldûn, IV, s. 151.

İbnü'l-Kûtiyye, s. 195-196; Ahbâru Mecmû'a, s. 27.

el-İmâme ve's-Siyâse, s. 224; Makkarî, I, s. 264.

el-İmâme ve's-Siyâse, s. 244.

İbnü'l-Kûtiyye, s. 196.
} 
geldiler. Mûsâ, Ifrîkıyye, Tanca ve Sûs valiliğine oğlu Abdullah $b$. Mûsâ'yı tayin etti. ${ }^{40}$ Buna karşıllık İbnü'l-Esîr, Mûsâ b. Nusayr'ın Septe şehrine ulaşınca Tanca, Septe ve çevresine oğlu Abdülmelik b. Mûsâ'yı, Ifrîkıyye bölgesine ise büyük oğlu Abdullah b. Mûsâ'yı tayin ettiğini nakletmektedir. ${ }^{41}$ Mûsâ, Kayravan şehrinde bulunurken Velîd b. Abdülmelik'in kendisini Şam'a çağıran ve biraz daha acele etmesini isteyen yeni bir mektubu geldi. Bunun üzerine Kayravan' dan yola çıan Mûsâ ve beraberindekiler Mısır'a kadar geldiler. Mûsâ'nın Mısır'a ulaştığını öğrenen Velîd, Mısır valisi Kurra b. Şerîk'e bir mektup göndererek, Mûsâ'ya Misır beytülmâlinden ne kadar isterse o kadar ödeme yapmasını emretti. Mûsâ b. Nusayr üç gün kadar Mısır'da kaldı ve istirahat etti. Bu süre içinde Mısır halkı ve ileri gelen kişiler Mûsâ'yı ziyaret ediyor ve onu görmeye geliyorlard1. 42

Mûsâ b. Nusayr'in Misır'da bulunduğu sırada halife Velîd hastalanmıştı. Velîd, hasta yatağından gönderdiği bir mektupla Mûsâ'nın Şam'a gelme konusunda acele etmesini istiyordu. Anlaş1dığına göre Velîd, ölmeden önce uzun yıllardır görüşmediği Mûsâ ile görüşmek, fetihlerle ilgili birinci kaynaktan bilgi almak istiyordu. Buna karşılık veliaht olan Süleyman b. Abdülmelik, Mûsâ'ya gönderdiği mektupta acele etmemesini ve bulunduğu yerde kalmasını istiyordu. Süleyman, Mûsâ'nın Endülüs'ten getirdiği eşsiz ganimetlerin kendisine kalmasını istiyor ve bunun için de kardeşi Velîd'in ölmesini bekliyordu. Böylece Mûsâ, birisi halifeden diğeri ise veliahttan gelen iki farklı mektubun muhatabı olmuştu. Mûsâ, Süleyman b. Abdülmelik'in mektubuna aldırış etmeden yoluna devam etti ve Velîd ölmeden önce Şam'a ulaşıp onunla görüştü. Elde ettiği tüm ganimetleri ve mücevherleri Velîd'e teslim etti. Fazla zaman geçmeden (bazı rivâyetlere göre 40 gün) Velîd öldü. ${ }^{43}$ Bazı tarihçiler, Mûsâ b. Nusayr Şam'a gelmeden önce Velîd b. Abdülmelik'in öldüğü ve Mûsâ'nın yeni halife olan Süleyman b. Abdülmelik'in huzuruna gelip onunla görüştüğünü naklederler. ${ }^{44}$

Bu husustaki iki farklı rivâyetin detayları şu şekildedir: Mûsâ b. Nusayr'ın Velîd döneminde Şam'a ulaştığını öne süren tarihçiler, Mûsâ'nın Şam'a gelişi ve Velîd'le görüşmesi olayını teferruatlı bir

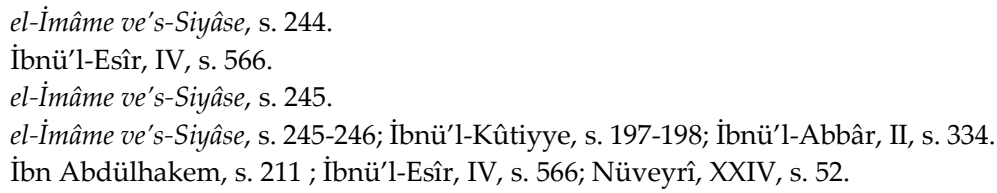


şekilde anlatırlar. Buna göre Mûsâ, 96/714-715 yılında Velid'in huzuruna geldi. Velîd'in vefatından 40 gün veya 2 ay kadar önce bir Cuma günü Şam'a giren Mûsâ, halife Velîd minberde iken camiye girdi. Mûsâ güzel elbiseler giymişti ve şık görünüyordu. Yanında esir olarak aldığı 30 tane melik çocuğu vardı. Bu çocukların başlarına hükümdar taçları giydirilmişti. Mûsâ çevresindeki hizmetçiler, esirler ve kalabalık heyet ile heybetli bir şekildeydi. Onları bu halde gören Velîd, şaşkınlık ve hayret içinde onları seyretti. Mûsâ minberin önüne kadar geldi ve Velîd'e selam verdi. Adamlarına minberin sağ ve sol yanına durmalarını emretti. Velîd kendisine bu geniş mülkü, iktidarı ihsan eden Allah (cc)'a şükretti. Daha sonra halka Cuma namazını kıldırdı. Velîd duayı, hamdi ve şükrü o kadar uzatmıştı ki, neredeyse Cuma namazının vakti çıkacaktı. Namazdan sonra Mûsâ b. Nusayr'1 yanına çağıran Velîd, ona bol bol bağışta bulundu. Mûsâ da getirdiği ganimetleri, mücevherleri ve Hz. Süleyman'a ait olduğu ifade edilen masayı halifeye teslim etti. ${ }^{45}$

Görüldüğü gibi son dönemlerini yaşayan halifeden sonra işbaşına gelecek olan veliaht Süleyman b. Abdülmelik, Mûsâ'nın yanında getirdiği paha biçilmez değerdeki mallar ve ganimetlerin kendisine ait olmasını istediği için onun Şam'a gelmeden beklemesini ve Velîd öldükten sonra gelmesini istemişti. Mûsa ise bu isteği dikkate almadan Şam'a gelerek Velîd ile görüşmüş ve ganimetleri ona teslim etmiştir. Bu olay daha sonra Mûsâ'nın Süleyman b. Abdülmelik'le olan ilişkilerini bozacaktır. Burada dikkat çeken nokta; Mûsâ b. Nusayr'ın on yıldır valiliğini yaptığı ve gerçekleştirdiği fetihlerde çoğu kere desteğini gördüğü halife Velîd'e karşı vefalı davranarak oyalanmadan Şam'a gelmesi ve emanetleri ona teslim etmiş olmasıdır. Mûsâ b. Nusayr bir İslâm komutanı olarak yapılması gereken davranışı sergilemiştir. Daha sonra başına gelecek tehlikeleri sezmemesi mümkün değildir. Buna rağmen Mûsâ'nın, konjonktüre uygun ve pragmatik davranmak yerine ahlâkî ve insânî bir davranış sergilemiştir. Bu şekilde Mûsâ, son dönemde bazı muhâlifleri ve saray çevresindeki dedikoducu kimselerin gayretleriyle halife Velîd ile bozulma sürecine giren ilişkileri düzeltmiş oldu. Kendisinin fetihlerinde teşvik edici rol oynayan Velîd'e karşı bir bakıma şükran borcunu ödedi.

Öte yandan Velîd'in Mûsâ'yı büyük bir ilgiyle karşılaması, ona lâyık olduğu şekilde davranması ve bir çok ihsanda bulunması Velîd b. Abdülmelik-Mûsâ b. Nusayr ilişkilerinin normal seviyede

45 İbnü'l-Kûtiyye, s. 197-198 ; İbn Kesîr, IX, s. 173. 
olduğunu göstermektedir. On yıl devam eden uzun bir süreçte elbette ilişkilerin aynı seviyede olmasını bekleyemeyiz. İnsan olmanın gereği olarak karşılıklı bazı hatalar olabilir. Ancak bu husustaki bir takım abartılı görüşlerin ve yorumların olduğu da tarih bir realitedir.

\section{b- Süleyman b. Abdülmelik-Mûsâ b. Nusayr İlişkilerinin Tahlîli}

Mûsâ b. Nusayr, Endülüs'te elde edilen ganimetlerle birlikte Şam'a gelip Velîd b. Abdülmelik ile görüştükten 40 gün veya iki ay sonra hasta olan halife Velîd vefat etti. Ondan sonra hilâfet makamina geçen Süleyman b. Abdülmelik ile Mûsâ b. Nusayr'ın ilişkileri hakkında ilk dönem kaynaklarında ve çağdaş araştırmalarda farklı yaklaşımlar mevcuttur. Genelde kabul edilen görüşe göre Mûsâ, Velîd'in hastalığının son dönemlerinde Şam'a ulaştı. Fazla zaman geçmeden Velîd ölünce yerine Süleyman b. Abdülmelik geçmişti. Süleyman halife olmadan önce henüz Mûsâ Şam'a ulaşmadan önce ona bir mektup yazarak acele etmemesini istemişti. ${ }^{46}$ Mûsâ'nın getirdiği eşsiz ve paha biçilemeyen ganimet mallarına sahip olmayı arzu eden Süleyman, bu isteğine uymayıp Şam'a gelerek Velîd ile görüşen Mûsâ'ya kızmıştı. Hatta Süleyman, Mûsâ b. Nusayr'ın kendi emrini dinlemeyip Şam'a doğru yola çıktığını öğrenince onu yakaladığ 1 zaman çarmıha gereceğine dâir yemin etti. ${ }^{47}$ Süleyman $b$. Abdülmelik'in Mûsâ'ya kızgınlığının başka bir sebebi, halife Velid'in son zamanlarında daha önceden veliahd olarak tayin edilen Süleyman'ın yerine oğlunu veliahd yapma düşüncesine diğer bazı valilerle birlikte Mûsâ b. Nusayr'ın ona destek vermesidir. Ayrıca Târık b. Ziyâd ile Muğ̂̂s er-Rûmî'nin Mûsâ'yı Süleyman'a şikayet ettiklerine dair nakiller de mevcuttur. Bu ikisi Mûsâ b. Nusayr'ın ganimet olarak elde edilen Hz.Süleyman'a ait masayı sahiplenmesi gibi bazı konuları halifeye jurnallemişlerdi. Hatta abartılı bir nakile göre Târık ve Muğ̣̂s, Mûsâ'nın ganimetler konusunda hıyanet ettiğini ve benzeri görülmemiş bir mücevheri kendisine ayırdığını söylemişlerdi. ${ }^{48}$ Böylece Târık ve Muğîs, Mûsâ'yı halifeye şikayet ederek zaten Mûsâ'ya kızgın olan halifenin ona olan kinini artırmı̧̧lardı. Târık ile Muğ̣̂s'in Endülüs'te Mûsâ b. Nusayr ile küçük bazı sürtüşmelere giriştikleri bilinmektedir. Bu konudaki farklı bir rivayeti nakleden İbn Abdülhakem'e göre ganimetlerle ilgili şikayeti

\footnotetext{
İbnü'l-Kûtiyye, s. 197-198.

el-İmâme ve's-Siyâse, s. 245-246.

Makkarî, I, s. 266.
} 
Mûsâ'nın ordusundaki askerlerden birisi olan İsâ b. Abdullah etTavîl yaptı. ${ }^{49}$

Velîd b. Abdülmelik veya bazı tarihçilerin nakillerine göre Süleyman b. Abdülmelik'in huzurunda meydana geldiği nakledilen bir diğer olay şu şekildedir: Mûsâ b. Nusayr fetihlerde elde ettiği ganimetleri halife Velîd'e teslim ederken Hz. Süleyman'a ait masayı da vermişti. Mûsâ bu masayı kendisinin ele geçirdiğini söyleyince orada bulunan Târık b. Ziyâd: "Hayır, onu ben ele geçirdim" dedi ve halifeye bu masanın eksik olan bacağını Mûsâ'ya sormasını istedi. Velîd bunu sorunca Mûsâ, bu hususta bilgisinin olmadığını ve onu bu şekilde bulduğunu söyledi. Bunun üzerine Târık, masanın eksik ayağını sakladığı yerden çıkartıp halife Velîd'e gösterdi. Böylece Velîd, bu hususta Târık'ın doğru söylediğini anladı. ${ }^{50}$ Makkarî'nin naklettiğine göre ise bu olay, Velîd öldükten sonra Süleyman'in huzurunda olmuştu. ${ }^{51}$

Süleyman b. Abdülmelik halife olduktan sonra bir gün Mûsâ b. Nusayr'1 huzuruna çağırarak ona bazı kötü sözler sarfetti. Süleyman, Mûsâ'ya Şam'a gelme hususunda acele etmemesi şeklindeki emrine aykırı davrandığı için gazaplandığını, onun yakınlarını ve adamlarını dağıtacağını, mallarına el koyacağını söylemiştir. Bunun üzerine Mûsâ, kendisinin önceki halifeye elçi olarak geldiğini, yanındaki ona (Velîd'e) ait olan malları muhafaza ettiğini ve emanetleri ona teslim ettiğini söyledi. ${ }^{52}$ Süleyman'ın Mûsâ'ya şu sözleri söylediği nakledilir: "Ben sana mektup yazdım. Sen benim mektubumu dikkate almadın. O halde ceza olarak 100.000 dînar öde." Bunun üzerine Mûsâ: “Ey Mü'minlerin emîri! Siz elimdeki tüm mallarıma el koydunuz. Ben 100.000 dînarı nereden bulayım" diye sorunca Süleyman: "Çare yok, 100.000 dînar ödeyeceksin" dedi. Mûsâ, halife Süleyman'dan özür dilemesine rağmen Süleyman'ın şöyle dediği nakledilir: "Senin 300.000 dînar ödemen gerekir." Hatta Süleyman'ın Mûsâ'ya işkence edilmesini istediği de ifade edilir. ${ }^{53}$

İbn Abdülhakem'e göre, bir adam Süleyman b. Abdülmelik'e giderek Endülüs'teki ganimetlerle ilgili olarak Mûsâ b. Nusayr'1 şikayet etmişti. Bunun üzerine Süleyman, Mûsâ'yı yanına çağırarak

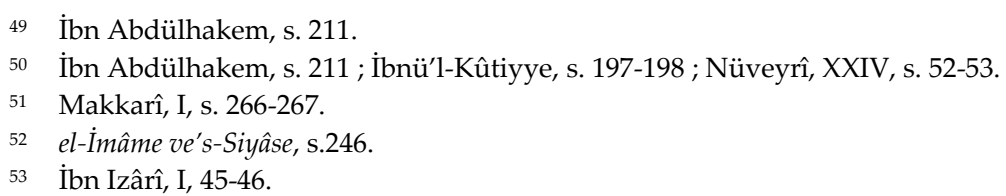


kendisi ve beraberindekilerin ihtiyaçlarını alıp Mağrib'e gitmesini istedi. ${ }^{54}$ Ancak İbn Abdülhakem'in naklettiği bu rivâyet diğer kaynaklarda yoktur. Buna karşılık Süleyman b. Abdülmelik'in Mûsâ'ya azap ettiği, çok sıcak bir yaz günü güneş altında saatlerce ayakta beklettiği nakledilmektedir. Buna göre yaşlı ve şişman olan Mûsâ bayılıncaya kadar güneş altında kalmıştır. Mûsâ'nın bu halini gören Ömer b. Abdülazîz çok üzülmüş ve şöyle demiştir: “O günden daha zor ve sıkıcı bir gün yaşamadım. Yaşlı Mûsâ'yı o halde gördüm. Allah (cc) yolundaki gayretlerinden sonra onun başına gelen bu şey ne kötüdür. Allah (cc) onun eliyle bir çok fetihler yaptırmıştır." Ömer b. Abdülazîz, halife Süleyman'ın huzuruna giderek Mûsâ'ya yapılan işin uygun olmadığını ve onun yaşlı bir komutan olduğunu söyledi. Ayrıca Mûsâ b. Nusayr'ın Allah yolunda bir çok fetihleri gerçekleştirdiğini de ilave etti. Ömer b. Abdülazîz'in bu sözleri Süleyman'ı yumuşattı ve yaptığından dolayı pişman oldu. Süleyman: "Kim onu zimmetine alır" diye sordu. Yezîd b. Mühelleb, Mûsâ b. Nusayr'ı zimmetine aldığını söyleyince Süleyman bu teklifi kabul etti. Süleyman, Yezîd b. Mühelleb'e: "O'na sıkıntı verme" dedi. Yezîd, Mûsâ'yı alıp evine götürdü. Mûsâ b. Nusayr günlerce Yezîd'in evinde kaldı. Daha sonra Süleyman ile Mûsâ arasında barış sağlandı ve halife ona önemli miktarda ihsanda bulundu veya para cezasından kalan borcunu affetti. ${ }^{55}$ Ömer b. Abdülazîz, bir görüşmeleri sırasında Mûsâ b. Nusayr'a şöyle demişti: “Ey İbn Nusayr! Şu dört şey için seni seviyorum: Allah (cc) yolunda gayret etmen, Hz. Muhammed (s.)'in Âline (Ehl-i beyt'ine) olan muhabbetin, Iyâd b. Ukbe'yi sevmen, bir de seninle babam (Abdülazîz b. Mervan) arasindaki irtibat." 56 Ömer b. Abdülazîz'in Mûsâ b. Nusayr hakkında bu derece olumlu ve güzel düşünceler taşıması ve onu Süleyman b. Abdülmelik'in elinden kurtarması dikkat çekmektedir. Bu aynı zamanda Mûsâ b. Nusayr'ın yaşadığı dönemde İslâm toplumu içinde seçkin bir konuma sahip olduğunu göstermektedir.

Süleyman b. Abdülmelik-Mûsâ b. Nusayr ilişkileriyle ilgili olarak İbnü'l-Kûtiyye'nin naklettiğine göre Süleyman işbaşına gelince Mûsâ b. Nusayr ve onunla birlikte olan Mağrib bölgesi görevlilerini sorguya çekti. Mûsâ ve beraberindekileri para cezasına çarptırdı. Para cezasının miktarı 100.000 dînar idi. Bunun üzerine Mûsâ, Yezîd b. Mühelleb'ten yardım istedi. Süleyman, Mûsâ'ya çok kızmıştı ve Hz. Süleyman'a ait masayı kendisinin ele geçirdiğini iddia etmesi

54 İbn Abdülhakem, s.211.

55 el-ìmâme ve's-Siyâse, s. 246-247.

56 el-İmâme ve's-Siyâse, s. 251. 
sebebiyle onu "yalancı ihtiyar" diye isimlendirmişti. Aslında Mûsâ yalan söylememiştir. Çünkü o masayı valisi ve azatlısı Târık b. Ziyâd ganimet olarak elde etmiş, diğer mallar ve ganimetlerle birlikte Mûsâ'ya teslim etmiştir. Endülüs'ün fethi nasıl nisbet edilmişse, o masa da kendisine nisbet edilmiştir. ${ }^{57}$

Bazı tarihçiler Süleyman b. Abdülmelik'in Mûsâ b. Nusayr'1 hapsettiği şekinde nakiller zikrederken ${ }^{58}$, bu olayın ne kadar sürdüğü konusunda bilgi vermemektedirler. İbnü'l-Esîr'e göre halife Süleyman, Mûsâ b. Nusayr'ı tüm görevlerinden azletmiştir. ${ }^{59}$ Mûsâ ile Süleyman b. Abdülmelik arasındaki bozuk ilişkilerinin uzun süre devam ettiğini öne sürenlerin yanısıra, bunun bir süre sonra bittiğini söyleyenler de mevcuttur. Birinci görüşte olanlara göre Mûsâ, tüm mallarına el konulduğu için para cezasını ödeyebilmek amacıyla ömrünün son yıllarında Araplardan para dilenmek zorunda kalmıştır. Ölümüne kadar Hicaz'da veya Vâdilkurâ'da perişan bir şekilde yaşamıştır. ${ }^{60}$ İkinci görüşte olanlara göre Süleyman'ın Mûsâ'ya olan kızgınlığı bir süre sonra geçmiş ve onu kendisine yaklaştırmıştır. Buna göre Süleyman b. Abdülmelik, Mesleme b. Abdülmelik'in Anadolu seferiyle ilgili Mûsâ'ya fikir danışmıştır. Yine bir defasında Süleyman, Mûsâ'ya Mağrib ve Endülüs ile ilgili sorular sormuş; Berberîler, Rumlar, İspanya halkı ve Franklar'ın genel özellikleriyle ilgili bilgiler almıştır. Mûsâ'nın bu sorulara verdiği detaylı cevaplar halifeyi hem memnun etmiş, hem de şaşırtmıştır. Bunların dışında halife Süleyman, 97/716 yılında hac yolculuğuna çıkarken giderken beraberinde yol arkadaşı olarak Mûsâ b. Nusayr'1 da götürmüştür. ${ }^{61}$

Halife Süleyman-Musa ilişkileri hakkında temel kaynaklardaki bu farklı ve zıt bilgiler konusunda çağdaş araştırmacılar da bazı değerlendirmelerde bulunmuşlardır. el-Haccî’ye göre, Süleyman b. Abdülmelik'in Mûsâ'ya karşı iyi davranmayıp ona eziyet ettiğiyle ilgili rivâyetlerde karışıklıklar, zıtlıklar ve mübalağalar vardır. O'na göre şayet Süleyman bu eziyetleri yapmış olsaydı, Mûsâ b. Nusayr'ın üç oğlunu valilik görevinde bırakmazdı. Süleyman, Mûsâ'yı ganimetlerdeki bazı tasarrufları sebebiyle hesaba çekmiştir. ${ }^{62} \mathrm{M}$.

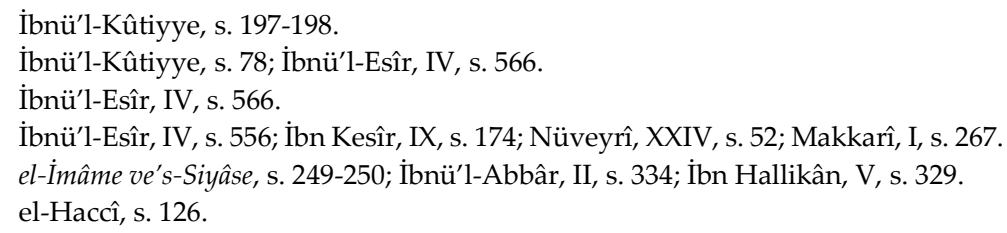


Abdullah Inân; Süleyman'ın Mûsâ'yı valilikten azlettiğini ve ona eziyet ettiğini ifade ettikten sonra Yezîd b. Mühelleb'in araya girmesiyle onu affettiğini ifade eder. ${ }^{63}$ Sadece Yezîd b. Mühelleb'in değil, Ömer b. Abdülazîz'in de bizzat halife Süleyman b. Abdülmelik'le görüşerek Mûsâ b. Nusayr'ın affedilmesini sağladığını daha önce ifade etmiştik. Hüseyn Mu'nis'e göre ise Mûsâ b. Nusayr'ın güneş altında bekletilmesi, dilenmeye mahkum edilmesi olayları sahih değildir. ${ }^{64}$

Kanaatimizce Süleyman b. Abdülmelik, kendi emrini dinlemeyip Endülüs'te elde ettiği ganimetleri hasta olan ve son günlerini yaşayan halife Velîd b. Abdülmelik'e getiren Mûsâ b. Nusayr'a kızmıştır. Halbuki Süleyman, ganimet mallarına kendisinin sahip olabilmesi için Mûsâ'ya yazdığı mektupta bir süre oyalanmasını ve Velîd öldükten sonra Şam'a gelmesini istemişti. Öte yandan Muğîs er-Rûmî ile Târık b. Ziyâd'ın Mûsâ'nın bazı uygulamalarıyla ilgili Süleyman b. Abdülmelik'e yaptıkları bazı ispiyonlar da ilişkileri olumsuz yönde etkileyen bir diğer faktördür. Tüm bunlardan sonra hilâfet makamına geçen Süleyman, Mûsâ'ya karşı sert bir politika izlemiş, onu kendisinden uzaklaştırmış ve ona eziyet ederek yüklü miktarda para cezasına çarptırmıştır. Ancak Süleyman'ın Mûsâ'ya karşı olan gazabının yıllarca devam ettiği görüşüne katlmak mümkün değildir. Çünkü Süleyman, bir süre sonra Ömer b. Abdülazîz ve Yezîd $b$. Mühelleb gibi hatırı sayılır kimselerin araya girmeleri sonucu Mûsâ'yı affetmiştir. Daha sonra Mûsâ'yı kendisine yaklaştırıp, hac yolculuğuna birlikte çıkmışlardır. Dolayısıyla Süleyman b. Abdülmelik'in Mûsâ b. Nusayr'la olan ilişkileriyle ilgili kaynaklardaki bazı rivâyetler iyi tahlil edilmelidir. Farklı nakiller gözardı edilerek tek bir rivâyetten yola çıkarak genel hükümler vermek uygun değildir. Bu hususta bazı çağdaş yazarların ${ }^{65}$ da ön yargılı yaklaşımlar sergiledikleri görülmektedir. Bir olayla ilgili olarak tarihçilerin vermiş oldukları farklı bilgilerin objektif bir şekilde incelenmesi ve ön yargıdan uzak bir şekilde değerlendirilmesinin önem arzettiği düşüncesindeyiz.

Süleyman b. Abdülmelik, Mûsâ b. Nusayr'a kızgın olduğu için hilâfete geçince ona karşı olumsuz tavır göstermiş ve ona eziyet etmek istemiştir. Ancak Süleyman sadece Mûsâ'ya değil meşhur Arap

63 M.Abdullah Inân, I, s. 57-58.

64 Hüseyn Mu'nis, Fecr, s. 108.

65 Mesela bkz: Bahriye Üçok, Emevîler-Abbasîler, s. 64-65; İsmet Parmaksızoğlu, "Mûsâ b. Nusayr", Türk Ansiklopedisi, XXIV, s. 456. 
komutanlarınadan bazılarına karşı kindar bir siyaset izlemiştir. Hatta abartılı olarak kabul edilebilecek bir rivâyete göre Süleyman, Haccâc b. Yûsuf ve Mûsâ b. Nusayr'ı ele geçirince çarmıha gereceğine dâir yemin etmiştir. Buna göre Süleyman, bir gün Ömer $b$. Abdülazîz'i yanına çağırarak: "Ben yarın Mûsâ b. Nusayr'ı idam edeceğim" dedi. Bunun üzerine Ömer b. Abdülazîz, Mûsâ'yı yanına getirtti. Kendisinin onu Allah (cc) yolunda gayret etmesi ve Allah (cc)'ın düşmanlarına karşı cihad etmesi vb. sebeplerle sevdiğini söyledi. Ayrıca Süleyman'ın onu idam etmek istediğini de haber verdi. Bunun üzerine Mûsâ'nın yıkanıp hazırlandığı nakledilir. Ertesi gün Süleyman, Mûsâ'yı huzuruna çağırarak ona kötü sözler söyledi. Mûsâ ise Allah (cc) yolunda cihad ettiğini ve bu cezayı haketmediğini söyledi. Süleyman: "Yalan söylüyorsun. Ben seni öldürmezsem Allah (cc) beni öldürür" dedi. Aralarında bazı konuşmalar daha yaptılar. Orada bulunan Ömer b. Abdülazîz, halife Süleyman'a yönelerek Mûsâ b. Nusayr'ın yaşlı birisi olduğunu ve onu affetmesinin uygun olacağını söyledi. Bunun üzerine Süleyman, Mûsâ'yı affetti ve onu Yezîd b. Mühelleb'in emânına terketti. Süleyman, Yezîd'e: “Mûsâ'yı sen al ve ona dokunma (eziyet etme). Oğlu Mervân'a ve Abdu'l-A'lâ'ya ise azap et!" dedi. ${ }^{66}$ Buradan da anlaşıldığına göre Süleyman'ın Mûsâ'ya olan kızgınlığı Mûsâ'nın ölümüne kadar devam etmedi. Buna rağmen bazı eserlerde işin bu yönüne hiç temas edilmeden Süleyman'ın Mûsâ'ya yaptıkları anlatılır. Herhangi bir yorumda bulunulmadan başka bir hususa geçilir.

Öte yandan Endülüs valisi Abdülaziz b. Mûsâ'nın öldürülmesi olayında halife Süleyman'ın rol oynadığına dair nakiller olması dikkat çekicidir. Daha önce belirtildiği gibi Mûsâ b. Nusayr Endülüs'ten Şam'a dönerken oğlu Abdülazîz b. Mûsâ'yı Endülüs'e vali olarak tayin etmişti. Abdülazîz b. Mûsâ, babası Mûsâ b. Nusayr'ın emri üzerine İşbiliyye (Sevilla) şehrini ülkenin merkezi yaptı. Endülüs'te İslâm egemenliğini pekiştirdi ve iç huzuru sağladı. Sınır bölgelerini tahkîm etti ve yeni bazı şehirler fethetti. Abdülazîz'in hayırlı ve seçkin bir vali olduğu ifade edilmektedir. ${ }^{67}$ Yolcuların ve tüccarların güvenliği için pek çok yerde kaleler ve karakollar kurdu. Levante hükümdarı Teodomiro ile anlaşma imzalad1. ${ }^{68}$ Endülüs'te toplumlararası evliliği teşvik etti ve kendisi de eski Vizigot kralı Rodrigo'nun dul eşi Egilona ile evlendi. Bu kadına "Ümmü Âsım"

66 el-İmâme ve's-Siyâse, s. 251-252 ; İbnü'l-Kûtiyyye, s. 167-168.

67 Makkarî, I, s. 268.

68 S. Muhammed Imâmuddin, s. 48; Mehmet Özdemir, Endülüs Müslümanlart-1, s. 35. 
ismi veriliyordu. Abdülazîz bu kadına özel önem veriyordu. O kadının ısrarı üzerine Abdülazîz'in oturduğu meclise küçük bir kapı açıldı. Böylece valinin huzuruna girecek olan herkes başını eğiyor ve sanki rükûya varmış gibi duruyordu. Bu iş Egilona'nın hoşuna gidiyordu. Çünkü Abdülazîz'in huzurunda secde ediliyormuş gibi oluyordu. ${ }^{69}$ Abdülazîz' in karısı ayrıca onun başına bir taç giymesini teklif etti. İspanya krallarının âdetinin böyle olduğunu söyleyip kocasını iknaya çalıştı. Bu teklife karşı Abdülazîz: "Bizim dinimizde böyle bir şey yoktur" diyerek karşı çıktı. Karısı ise: "Ben seninle yalnızken senin dindaşların bunu nereden görüp bilecek?" dedi. Fazla zaman geçmeden Abdülazîz'e dediğini yaptırdı. Bir gün Ziyâd b. Nâbiğa et-Temîmî'nin karısı onu başında taç olduğu halde gördü ve bu durumu kocasına haber verdi. Ziyâd b. Nâbiğa da bunu Hubeyb b. Ebî Ubeyde b. Ukbe b. Nâfi'ye söyledi. Böylece ordunun komutanları ve ileri gelenleri arasında bu olay duyuldu. Daha sonra kendi gözleriyle Abdülazîz'i başında taç olduğu halde gördüklerinde onun din değiştirip Hıristiyan olduğu vehmine kapıldılar. O'na hücum edip öldürdüler. Kesik başını da Şam'daki halife Süleyman b. Abdülmelik'e gönderdiler. ${ }^{70}$

Endülüs tarihiyle ilgili kaynaklardan birisi olan müellifi meçhul "Ahbâru Mecmû'a" adlı eserde, Abdülazîz b. Mûsâ'nın öldürülmesi olayının tertipleyicisinin Süleyman b. Abdülmelik olmadığı ifade edilmektedir. Buna göre Abdülazîz'in öldürüldüğünü öğrenen halife Süleyman bu olaya üzülmüştür. Süleyman bu olaydan sonra Ifrîkıyye valiliğine Abdullah b. Yezîd'i tayin etmiş ve Abdülazîz'in öldürülmesi olayına katılan kişilerin sorgulanmak üzere kendisine gönderilmesini emretmiştir. ${ }^{71}$ Çağdaş araştırmacılardan M. Seyyid el-Vekîl de Abdülazîz b. Mûsâ'nın öldürülmesi olayında Süleyman b. Abdülmelik'in rolünün olmadığı görüşündedir. ${ }^{72}$

Bu olayda halifenin bilgisi olduğunu öne sürenlere göre, Abdülazîz b. Musâ'nın kesik başı Süleyman'ın huzuruna getirilince Mûsâ b. Nusayr'ı huzuruna çağırdı. Halife Süleyman, Mûsâ'ya: “Bunu tanıdın mı?" diye sordu. Mûsâ: "Evet, onu oruç tutan ve namaz kılan birisi olarak bilirim" dedi ve oğlunu öldürenlere Allah (cc)'nn lânet

\footnotetext{
69 İbnü'l-Esîr, V, s. 22.

70 Ahbâru Mecmû'a, s. 28; Merrakuşî, s. 35; Philip K.Hitti, III, s. 792. Bu konuda geniş bilgi için bkz: Atçeken, İsmail Hakkı, "İlk Endülüs Valisi Abdülazîz b. Mûsâ b. Nusayr ve Öldürülmesi", S.Ü.I.F.D. sayı: 14, s. 65-87.

71 Ahbâru Mecmû'a, s. 29.

72 M. Seyyid el-Vekîl, el-Ümeviyyûn beyne'ş-Şark ve'l-Ğarb, II, s. 82.
} 
edeceğini söyledi. ${ }^{73} \mathrm{Bu}$ üzücü olaya bir baba olarak Mûsâ b. Nusayr'ın üzülmemesi düşünülemez. Mûsâ, oğlu hakkındaki iddiaların aksine onun Müslüman olduğu halde öldürüldüğünü ve bunu haketmediğini düşünüyordu. Abdülazîz $b$. Mûsâ'nın öldürülmesi Endülüs'te istikrarın ve iç huzurun bozulmasına yol açtı. Bundan sonra başlayan valiler döneminde asabiyye problemi ortaya çıtı. Arap kabileleri arasındaki çekişmelerin yanısıra, Arap-Berberî anlaşmazlığı önemli bir iç problem olarak kendini gösterdi. Artık bölgede yeni fetih projeleri yerine bazı iç sıkıntılar ve çekişmeler gündemdeydi.

\section{c- Mûsâ b. Nusayr'ın Ölümü:}

Mûsâ b. Nusayr'ın ölüm tarihi konusunda 97/716 74 , 98/717. ${ }^{75}$ veya 99/718 yılı verilmektedir. ${ }^{76}$ Humeydî ve İbn Kesîr, Mûsâ b. Nusayr'ın ölüm yılı olarak önce 97/716 yılını verdikten sonra 99/718 y1lının da söylendiğini ilave etmektedirler. Yani tek bir rivâyeti tercih etmeyerek her iki görüşü de nakletmişlerdir. Buna rağmen tarihçilerin çoğunlukla kabul ettikleri tarih 97/716 yılıdır. Tarihî olayların seyrine uygun olan tarih 97/716 yılıdır. Nitekim çağdaş araştırmacılardan el-Haccî de, Mûsâ b. Nusayr'ın vefat yılı olarak 97/716 yılının doğru olduğunu, bu yıldan sonra Süleyman b. Abdülmelik'in bir daha haccetmediğini ifade etmektedir. ${ }^{77}$ Mûsâ da halife Süleyman'la birlikte gittiği hac sırasında vefat ettiğine göre bu yıl ölmesinin daha mantıklı olduğunu düşünüyoruz.

Süleyman b. Abdülmelik önceleri Mûsâ b. Nusayr'a karşı kötü muamele edip cezalandırmasına rağmen Ömer b. Abdülazîz'in araya girmesi ve ricasıyla onu affederek Yezîd b. Mühelleb'in zimmetine bırakmıştı. Daha sonraları Mûsâ'yı kendisine yaklaştırmış ve ilişkileri düzeltmişti. Nakledildiğine göre Süleyman $b$. Abdülmelik 97/716 yılında haccetmek amacıyla Hicaz'a gitmeye karar verdi. Süleyman hacca birlikte gitmek için Mûsâ'ya teklifte bulununca o da kabul etti. Birlikte haccı yaptıktan sonra yolda konuşarak Medine'ye kadar geldiler. Medine'de bulundukları sırada Mûsâ b. Nusayr yakınındaki güvendiği dostlarına şöyle dedi: "İki güne kadar

73 İbn Abdülhakem, s.213; İbnü'l-Abbâr, II, s. 334.

74 İbn Abdülhakem, s. 213 ; İbnü'l-Esîr, V, s. 26; Humeydî, s. 317; İbnü'l-Faradî, II, s. 144; İbnü'l-Abbâr, II, s. 334; Zehebî, Düvel, s. 68; Yafiî, I, s. 159; İbn Kesîr, IX, s. 174; Makkarî, I, s. 273.

75 el-İmâme ve's-Siyâse, s. 259; İbn Izârî, I, s. 174.

76 Humeydî, s. 317; İbn Kesîr, IX, s. 174.

77 el-Haccî, s. 127-dipnot 1. 
şanı doğuya ve batıya kadar uzanmış olan birisi ölecek." Yanındakiler Mûsâ'nın bu sözüyle halife Süleyman'ı kastettiğini zannettiler. İkinci gün olunca Rasûlullah (s.)'n mescidinde bulunan insanlar: "Mûsâ b. Nusayr öldü" diyerek birbirleriyle konuştular. Mûsâ'nın namazını bizzat Süleyman b. Abdülmelik kıldırdı ve cenazesi Medine'de defnedildi.78 Mûsâ'nın Medine'de değil, Vâdilkurâ'da öldüğü de nakledilir. ${ }^{79}$ Bunların yanısıra hac yolunda vefat ettiğini rivâyet edenler de vardır. ${ }^{80}$

Tarihçilerin naklettikleri rivâyetlerde genelde ortak olan husus; Mûsâ b. Nusayr'ın Süleyman b. Abdülmelik'le birlikte hac yolculuğuna çıkmış olmasıdır. Vefat ettiği yer konusu ise aynen vefat yılı gibi tartışmalıdır. Ifrîkıyye ve Mağrib valiliği zamanında meydana gelen kıtlık olayında yağmur duasına çıktığına Mûsâ b. Nusayr duasının sonunda şöyle demişti: "Allahım! Kendim için ya senin yolunda şehit olmayı, ya da Rasûlünün şehrinde (Medine'de) vefat etmeyi isterim." 81 Şayet Mûsâ b. Nusayr'ın Medine'de öldüğü doğruysa duasının kabul olduğu anlaşılmaktadır.

\section{Sonuç}

Mûsâ b. Nusayr 19/640 yılında doğmuş ve tercih edilen görüşe göre 97/716 yılında vefat etmiştir. Öldüğünde yaşı yetmiş altının üzerindedir. Genelde kabul edildiği şekilde 86/705 yılında tayin edildiği Ifrîkıyye ve Mağrib valiliğini on yıldan fazla sürdürmüştür. 93/712 yılında Endülüs'e geçmiş ve burada iki yıl kadar kaldıktan sonra 95/714 yılında Şam'a geri dönmüştür. Ömrünün son iki yılı Şam’da geçmiş ve Süleyman b. Abdülmelik'le birlikte çıtığı hac yolculuğu sırasında 97/716 yılında vefat etmiştir. Mağribu'l-Aksâ ve Endülüs'ü Târık b. Ziyâd'la birlikte fetheden, Akdeniz'deki bazı önemli adaları ele geçiren ve tâbiînden olan Mûsâ b. Nusayr ömrünün çoğu fetihlerle geçtiği halde kendi yatağında eceliyle ölmüştür. Mûsâ $b$. Nusayr, İslâm tarihinde çok önemli fetihler gerçekleştiren seçkin bir fâtih, komutan ve vali olarak yerini almıştır. Mûsâ b. Nusayr askerî seferlerin yanısıra Ifrîkıyye ve Mağrib bölgesinde bazı idârî düzenlemeler de yapmıştır. Kendisinden önce askerî üs olarak kurulan Kayravan'dan sonra yeni fethettiği Tanca şehrini Müslümanlar için ikinci bir askerî karargah şehri haline getirmiştir. Bu şehre Berberî

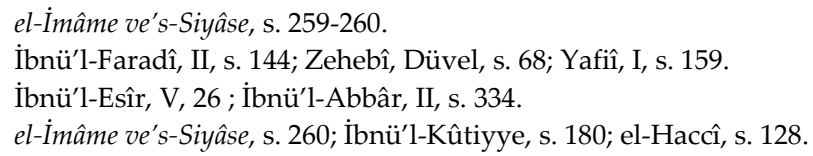


asıllı azatlısı Târık b. Ziyâd'ı vali olarak tayin eden Mûsâ, onun yanına 17.000 Arap, 12.000 Berberî asker yerleştirmiştir. Bundan sonra Tanca, fetih hareketleri açısından önemli bir askerî karargah şehri haline gelmiş oldu. Musa b. Nusatr, akıllı, cesaretli, ciddî, tedbir sahibi, muttakî, dindar bir idareci olmasının yanısıra iyi bir asker ve komutandır. O'nun ordusunun katıldığı savaşlarda hiçbir zaman hezimete uğramadığı ve her zaman zafer kazandığı belirtilir. Mûsâ b. Nusayr, Endülüs'ü fethettikten sonra batı Avrupa yoluyla İstanbul'a ve oradan da Şam'a ulaşmayı bir ideal olarak hedeflemişti. Ayrıca o, ilk defa Fransa topraklarına girip fetihler gerçekleştirerek bu konuda da İslâm tarihinde ilk olma şerefine sahip olmuştur

95/714 yılına kadar iki yıl kadar Endülüs'te fetihleri tamamlayan Mûsâ b. Nusayr, aynı yıl halife Velîd b. Abdülmelik'in kendisini Şam'a çağırması üzerine Endülüs'ten ayrılıp Şam'a geri döndü. Mûsâ'nın gerek Velîd b. Abdülmelik, gerekse ondan sonra halife olan Süleyman b. Abdülmelik'le olan ilişkileri oldukça ilginç bir gelişme takip etmiştir. Bu konularla ilgili tüm rivâyetler ve görüşler incelenmeli, meseleye tek bir noktadan veya bir tarihçinin bakış aç1sıyla değil, geniş bir perspektiften bakmak gerekmektedir. Süleyman b. Abdülmelik'in Mûsâ'ya kızgınlığının bir sebebi, halife Velid'in son zamanlarında daha önceden veliahd olarak tayin edilen Süleyman'ın yerine oğlunu veliahd yapma düşüncesine diğer bazı valilerle birlikte Mûsâ b. Nusayr'ın da Velîd'e destek vermesidir. Ayrıca Târık b. Ziyâd ile Muğîs er-Rûmî'nin ganimetlerle ilgili bazı uygulamaları sebebiyle Mûsâ'yı Süleyman'a şikayet ettiklerine dair nakiller mevcuttur. Bu ikisi Mûsâ b. Nusayr'ın ganimet olarak elde edilen Hz.Süleyman'a ait masayı sahiplenmesi gibi bazı konuları halifeye jurnallemişlerdi. Mûsâ b. Nusayr'ın ömrünün son dönemleri ve âkıbeti hakkında bazı farklı nakiller ve yorumlar mevcuttur. Süleyman b. Abdülmelik'in gazabına uğrayarak valilikten azledildiği, para cezasına çarptırıldığı ve perişan halde öldüğüyle ilgili trajik bilgiler veren bazı tarihçiler vardır. Bunun yanısıra Ömer $b$. Abdülazîz'in araya girmesiyle halife Süleyman'ın Mûsâ'yı affettiğini, onu kendisine yaklaştırdığını, 97/716 yılında hacca giderken Mûsâ'yı da yanında götürdüğünü, Mûsâ'nın bu sırada Medine'de vefat ettiğini haber verenler de mevcuttur. Bu hususta ikinci grup rivâyetlerin daha tercihe layık olduğu düşüncesindeyiz.

Mûsâ b. Nusayr'ın on yıldır valiliğini yaptığı ve gerçekleştirdiği fetihlerde çoğu kere desteğini gördüğü halife Velîd'e karşı vefalı davranarak oyalanmadan Şam'a gelmesi ve emanetleri ona teslim etmesi bir İslâm komutanı olarak yapılması gereken davranıştır. 
O'nun daha sonra başına gelecek tehlikeleri sezmemesi mümkün değildir. Buna rağmen Mûsâ konjonktüre uygun ve pragmatik davranmak yerine ahlâkî ve insânî bir davranış sergilemiştir.

\section{Kaynakça}

Ahbâru Mecmû'a fî Fethi'l-Endelüs ve Zikri Ümerâihâ, (Müellifi meçhul) thk: İbrâhim el-Ebyârî, Beyrut, 1981.

Atçeken, İsmail Hakkı, Endülüs'ün Fethi ve Mûsâ b. Nusayr, Ankara, 2002.

Atçeken, İsmail Hakkı, “ilk Endülüs Valisi Abdülazîz b. Mûsâ b. Nusayr ve Öldürülmesi", S.Ü.I.F.D, sayı:14, Konya, 2002/Güz.

Belâzurî, Fütûhu'l-Büldân (Ülkelerin Fethi), çev:Mustafa Fayda, Ankara, 1987.

Fayda, Mustafa, Allah'ın Kılıcı Hâlid b. Velid, 2.baskı, İstanbul, 1992.

Haccî, Ali Abdurrahman, et-Târîhu'l-Endelüsî, 5.baskı, Dımeşk, 1997

Hammâde, Muhammed Mâhir, el-Vesâiku's-Siyâsiyye ve'l-İdâriyye li'lAsri'l-Ümevî, 2.baskı, Beyrut, 1983.

Himyerî, er-Ravdu'l-Mi'târ fî Haberi'l-Aktâr, 2.baskı, Beyrut, 1984.

Humeydî, Cezvetü'l-Muktebis, thk: Muhammed b.Tâvit et-Tancî, Kahire, 1953.

Hüseyn Mu'nis, Târîhu'l-Müslimîn fî Bahri'l-Mütevessit, 2.baskı, Kahire, 1993.

Imâmuddin, S.Muhammed, Endülüs Siyâsî Tarihi, çev: Yûsuf Yazar, Ankara, 1990.

Inân, M.Abdullah, Devletü'l-İslâm fi'l-Endelüs, 2.bask1, Kahire, 1988.

Istahrî, Mesâliku'l-Memâlik, ed: M.J. De Goeje, Leiden, 1927'den ofset (Beyrut, tsz).

İbn Abdülhakem, Fütûhu Mısr ve Ahbâruhâ, thk: Charles C.Torrey, Kahire, 1991.

İbn Haldûn, Târîhu İbn Haldûn, thk: Halîl Şehâde, 2.baskı, Beyrut, 1988.

İbn Hallikân, Vefeyâtu'l-A'yân ve Enbâu Ebnâi'z-Zamân, thk: İhsan Abbas, Beyrut, 1977.

İbn Hazm, Cemheratu Ensâbi'l-Arab, Beyrut, 1983.

İbn Hurdâzbih, el-Mesâlik ve'l-Memâlik, ed: M. J. De Goeje, Leiden, $1889^{\prime}$ dan ofset (Beyrut, tsz).

İbn Izârî, el-Beyânü'1-Muğrib fî Ahbâri'l-Endelüs ve'1-Mağrib, thk: G.S.Colin-E.Levi Provençal, Beyrut, 1983.

İbn Kesîr, el-Bidâye ve'n-Nihâye, 2. Baskı, Beyrut, 1990.

İbnü'l-Abbâr, el-Hulletü's-Siyerâ, thk: Hüseyn Mu'nis, 2. baskı, Kahire, 1985.

İbnü'l-Esîr, el-Kâmil fi't-Târîh, Beyrut, 1965.

İbnü'l-Faradî, Târîhu'l-Ulemâi ve'r-Ruvât li'l-Âlem bi'l-Endelüs, 2. bask1, Kahire, 1988 
İbnü'l-Kûtiyye, Târîhu İftitâhi'l-Endelüs, thk: Abdullah Enîs et-Tabba'Ömer Faruk et-Tabba', Beyrut, 1994.

el-İmâme ve's-Siyâse (İbn Kuteybe'ye nispet edilmektedir), thk: Halîl elMansûr, Beyrut, 1997.

Kaymakçı, Salih, Târık b. Ziyâd Hayatı ve Şahsiyeti (Basılmamış Yüksek Lisans Tezi), Konya, 2000.

K. Hitti, Philip, Siyâsî ve Kültürel İslâm Tarihi, çev: Salih Tuğ, İstanbul, 1989.

Makkarî, Nefhu't-Tîb min Ğusni'l-Endelüsi'r-Ratîb, thk: Yûsuf eş-Şeyh elBukâî, Beyrut, 1986.

Merrakuşî, el-Mu'cib fî Telhîsi Ahbâri'l-Mağrib, thk: M. Saîd el-Uryân, Kahire, tsz.

Mevsûatu Târîhi'l-Mağribi'l-Arabî, Kahire, 1994.

Nüveyrî, Nihâyetü'l-Ereb fî Funûni'l-Edeb, thk: Hüseyn Nassâr, Kahire, 1983.

Özdemir, Mehmet, Endülüs Müslümanları-1, Ankara, 1994.

Özkuyumcu, Nadir, Fethinden Emevîler'in Sonuna Kadar Mısır ve Kuzey Afrika (Basılmamış Doktora Tezi), İstanbul, 1993.

Parmaksızoğlu, İsmet, "Mûsâ b. Nusayr", Türk Ansiklopedisi, Ankara, 1976.

Ronart, Stephen, “Mûsa İbn-Nusayr", CEAC, Amsterdam, 1959.

Sûfî, Hâlid, Târîhu'l-Arab fi'l-Endelüs, Bingazi, 1980.

Sûyûtî, Târîhu'l-Hulefâ, thk: Muhammed Muhyiddin Abdilhamîd, Misır, tsz.

Taberî, Târîhu'l-Ümemi ve'l-Mulûk, Beyrut, 1987.

el-Ubûdî, Câsim, “Mûsâ b. Nusayr", DİA, XXXI, İstanbul, 2006.

Üçok, Bahriye, Emevîler-Abbasîler, Ankara, 1979.

Vekîl, M. Seyyid, el-Ümeviyyûn beyne'ş-Şark ve'l-Ğarb, Dımeşk, 1995.

Yafiî, Mir'âtü'l-Cinân, thk: Halil Mansûr, Beyrut, 1997.

Yâkût el-Hamevî, Mu'cemü'l-Büldân, thk: Ferîd Abdülazîz el-Cündî, Beyrut, 1990.

Zehebî, Düvelü'l-İslâm, thk: Fehim Muhammed Şeltût-M.Mustafa İbrahim, Misir, 1974.

Zehebî, Târîhu'l-İslâm (H.81-100), thk: Ömer Abdüsselâm Tedmürî, 2.bask1, Beyrut, 1993.

Ziriklî, Hayruddin, el-A'lâm Kâmusu Terâcim, 3. baskı, Beyrut, 1969. 


\section{Mílel VE NiHAL}

inanç, kültür ve mitoloji araştırmaları dergisi

Cilt/Volume: 12 Sayı/Number: 1 Ocak - Haziran / January - June 2015

ISSN: 1304-5482

Bu dergi uluslararası EBSCO HOST Research Databases veri indeksi ve

TÜBİTAK-ULAKBİM Sosyal ve Beşeri Bilimler Veri Tabanı tarafından taranmaktadır.

\section{Sahibi / Owner}

Milel ve Nihal Eğitim, Kültür ve Düşünce Platformu Derneği adına Şinasi Gündüz

$$
\begin{gathered}
\text { Yazı İşleri Sorumlusu / Legal Representative } \\
\text { Yasin Aktay }
\end{gathered}
$$

Editör / Editor

Şinasi Gündüz

Editör Yrd. / Co-Editor

Cengiz Batuk

Hakan Olgun

\section{Sayı Editörü / Editor of Issue}

Feridun Bilgin

Yayın Kurulu/ Editorial Board*

Alpaslan Açıkgenç, Ayaz Akkoyun, Yasin Aktay, Mahmut Aydın,

Cengiz Batuk, Şinasi Gündüz, İbrahim Kayan, Hakan Olgun, Necdet Subaşı, Burhanettin Tatar

\section{Danışma Kurulu/Advisory Board*}

Baki Adam (Prof. Dr., AÜ); Mohd. Mumtaz Ali (Prof. International Islamic U. Malezya); Adnan Aslan (Prof.Dr., Süleyman Şah Ü.); Kemal Ataman (Doç.Dr., Uludağ Ü.); Mehmet Akif Aydın (Prof. Dr., Marmara Ü.); Yılmaz Can (Prof. Dr., OMÜ); Ahmet Çakır (Doç. Dr., OMÜ); Mehmet Çelik

(Prof. Dr., Celal Bayar Ü.); Waleck S. Dalpour (Prof. University of Maine at Farmington); İsmail

Engin (Dr., Berlin); Cemalettin Erdemci (Prof.Dr. YYÜ); Tahsin Görgün (Prof.Dr., 29

Mayıs Ü.) Ahmet Güç (Prof.Dr., Uludağ Ü.); Recep Gün (Doç. Dr., OMÜ); Ö. Faruk Harman

(Prof.Dr., Mar.Ü.); Erica C.D. Hunter (Dr., Cambridge U.); Mehmet Katar (Prof. Dr., A.Ü.);

Mahmut Kaya (Prof. Dr., İ.Ü.); Sadık Kılıç (Prof.Dr., Atatürk Ü..); Şevket Kotan (Y.Doç.Dr., İ.Ü.);

İlhan Kutluer (Prof.Dr., Mar. Ü.); George F. McLean (Prof. Catholic Univ., Washington DC); Ahmet Yaşar Ocak (Prof. Dr., Hacettepe Ü.); Jon Oplinger (Prof. University of Maine at Farmington); Ömer

Özsoy (Prof.Dr., Frankfurt U.); Roselie Helena de Souza Pereira (Mestre em

Filofia-USP; UNICAMP Brasil); Ekrem Sarıkçığlu (Prof.Dr., SDÜ); Hüseyin Sarıoğlu (Prof.Dr.,

IÜ); Bobby S. Sayyid (Dr. Leeds U.); Mustafa Sinanoğlu (Prof.Dr., 29 Mayıs Ü.); Mahfuz Söylemez

(Prof.Dr. İÜ); Necdet Subaşı (Y.Doç.Dr., DİB); Bülent Şenay (Prof.Dr., UÜ); İsmail Taşpınar

(Prof.Dr. Mar.Ü.); C. Sadık Yaran (Prof.Dr., OMÜ); Ali Murat Yel (Prof.Dr., Fatih Ü.); Hüseyin Yılmaz (Doç.Dr., YYÜ); Ali İhsan Yitik (Prof. Dr., DEÜ)

$$
\text { * Soyadına göre alfabetik sıra / In alphabetical order }
$$

\section{Kapak ve Sayfa Tasarımı / Cover \& Page Design} İnan $\mathrm{Avc1}$

\section{Baskı / Publication}

Ladin Ofset - İstanbul, Ekim 2015

2.Mat. Sit. 3 NB 15 Topkapi İstanbul / İsmail Tüz 02125012418

Yönetim Yeri / Administration Place

Milel ve Nihal Eğitim, Kültür ve Düşünce Platformu Derneği

Fevzipaşa Cad. Şehit Mehmet Sarper Alus Sok. No: 5, K.: 3, Tel: (0212) 5339731 Fatih/İstanbul www.milelvenihal.org e-posta: dergi@milelvenihal.org

Milel ve Nihal yılda iki sayı olarak altı ayda bir yayımlanan uluslararası hakemli bir dergidir.

Milel ve Nihal' de yayımlanan yazıların bilimsel ve hukuki sorumluluğu yazarlarına aittir. Yayım dili Türkçe ve İngilizce' dir. Yayımlanan yazıların bütün yayın hakları Milel ve Nihal'e ait olup, yayıncının izni olmadan kısmen veya tamamen basılamaz, çoğaltılamaz ve elektronik ortama taşınamaz. Yazıların yayımlanıp yayımlanmamasından yayın kurulu sorumludur. 


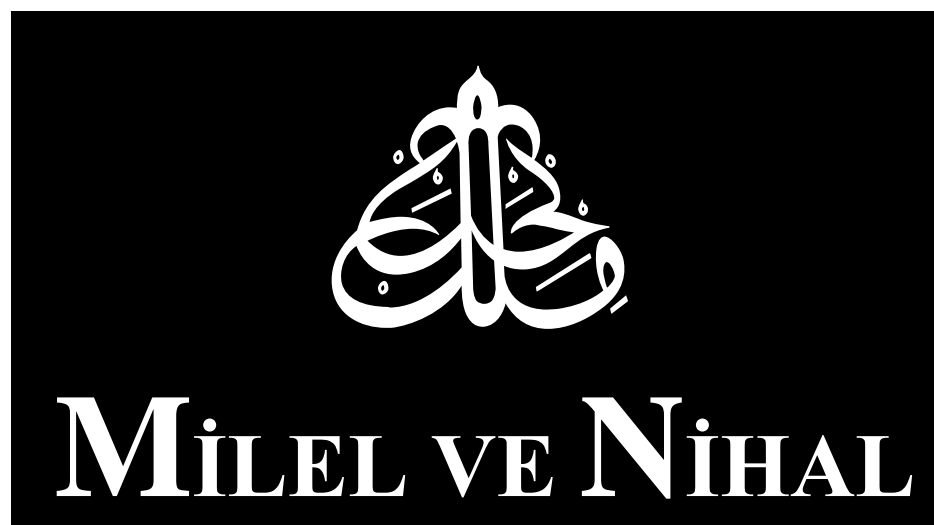

inanç, kültür ve mitoloji araştırmaları derogisi

ISSN: 1304-5482

ENDÜLÜS

Cilt/Volume: 12 Sayı/Number: 1

Ocak - Haziran / J anuary - June 2015 
